\title{
Drivers of Durable Peace: The Role of Justice in Negotiating Civil War Termination
}

\author{
Lynn Wagner ${ }^{1,5}$. Daniel Druckman ${ }^{2,3,4,5}$
}

Published online: 7 October 2016

(C) The Author(s) 2016. This article is published with open access at Springerlink.com

\begin{abstract}
Attaining durable peace after a civil war has become a major challenge, as many negotiated settlements relapse into violence. How can civil war negotiations be conducted and peace agreements formulated so as to contribute to lasting, durable peace? Previous research has focused on the durability of peace agreements, measured as the absence of violence. This study develops an index to measure durable peace for a period of 8 years after the agreement had been reached, and evaluates the new measure using an existing data set. We ask whether impacts on durable peace are
\end{abstract}

\footnotetext{
Support for this study was provided by a Swedish Research Council Grant [C0114201; Registration Number 421-2012-1142] for a research Project titled "From peace negotiations to durable peace: The multiple roles of justice." Special thanks go to Sayra van den Berg for her diligent assistance with the coding and to the many colleagues who provided helpful advice on earlier drafts including those who heard our presentations at the International Studies Association (New Orleans, March 2015) and at the International Association for Conflict Management (Clearwater, Florida, June 2015).
}

Electronic supplementary material The online version of this article (doi:10.1007/s10726-016-9511-9) contains supplementary material, which is available to authorized users.

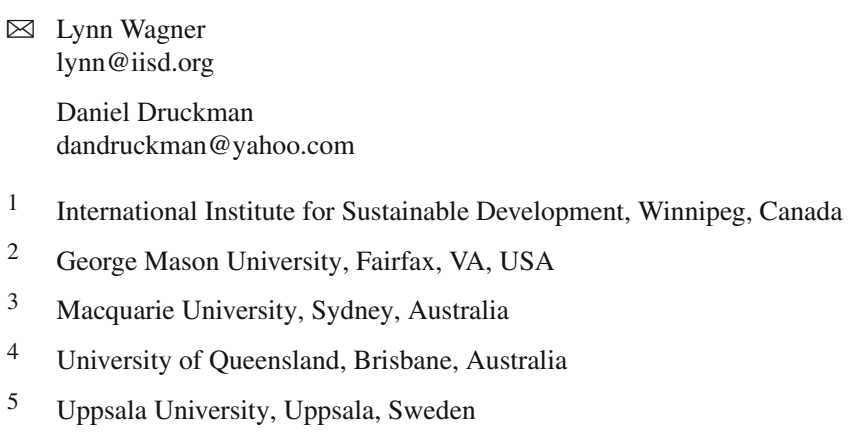


similar or different to those found for the durability of agreements. This question suggests a number of hypotheses that are evaluated with 16 cases of peace agreements. Stable agreements are shown to mediate the relationship between equality provisions in peace agreements and durable peace, and to also mediate the relationship between procedural justice and the reconciliation component of durable peace. Interestingly, economic stability is not a dividend of peace agreements.

Keywords Civil war negotiations - Conflict environment - Distributive justice • Stable agreements $\cdot$ Durable peace $\cdot$ Equality $\cdot$ Procedural justice

\section{Introduction}

The 1991 Bicesse Accords in Angola. The 1992 Chapultepec Peace Agreement in El Salvador. The 1995 General Framework Agreement for Peace in Bosnia and Herzegovina. The 1996 Abidjan Peace Agreement in Sierra Leone. The names of these peace agreements are familiar to those who study international conflict resolution, as four examples of efforts to resolve violent clashes within national boundaries. More importantly, citizens within these war-torn countries have held up the names of these and similar agreements for their promise to bring tranquility for their villages and families. The agreements, however, have not always resulted in lasting, durable peace. This paper seeks to increase understanding of how these agreements could lead to lasting peace.

The expanding literature on peace agreements informs this study, particularly in identifying the variables that influence implementation of the agreements. However, the literature is inconclusive regarding what constitutes durable peace; this study offers an approach to assess this concept and evaluate relationships among negotiation process, outcome and durable peace, including its components, beyond the more traditional assessment of an absence of violence. Many studies assess "peace" based on the length that a peace agreement remains in force (Salehyan and Thyne 2012: 199). Martin (2013), for example, uses a dependent variable labeled 'Peace Duration', which measures the number of months from the signing of the agreement until its failure. The main contribution of this research is the development of a new index that goes beyond the absence of active conflict (or negative peace). In addition, this research considers the relationship between durable peace and justice variables during the negotiation of the agreement, to explore research questions that can be evaluated with the durable peace index.

\section{Constructing a Durable Peace Index}

Stable agreements that keep the conflict in check through cease fires and related provisions that manage a conflict can be viewed as conflict management. Durable peace, on the other hand, concerns the extent to which the conflict is resolved. In the latter case, peace is achieved in the war-torn, post-conflict society and is assessed over a relatively long period of time. Durable peace occurs when the former combatants reconcile their differences and rebuild security, governmental and economic institutions. 
Distinguishing between conflict management and resolution (Druckman 2002), postconflict states can be evaluated in terms of their success on two dimensions: managing and resolving conflicts.

Much of the peace agreement research to date has focused, in effect, on conflict management. Efforts to define the components of conflict resolution, or durable peace, have been as elusive as efforts to achieve it, in large part due to the fact that it involves multiple variables (Downs and Stedman 2002). The issues addressed in the peace agreements themselves offer important insights into the variables that warring parties (and their allies) believe will be important components for building lasting peace. Studies of the relationships between the contents of peace agreements and whether violence resumes have identified some of the variables that contribute to conflict resolution. Hartzell and Hoddie (2003: 318), for example, find a statistical relationship between higher levels of power sharing provisions in peace agreements, which "define how decisions are to be made within a divided society and the distribution of decision making rights within a state," and longer periods during which peace endures after the settlements are signed. Fortuna (2004) identifies variables that influence the "baseline" prospects for peace, and evaluates how these variables affect the content of cease fire agreements and how this content, in turn, impacts on the durability of peace, measured in the traditional approach as the absence of war. The civil war recurrence literature identifies variables that capture the outcome of the previous civil war and those that relate to estimates of the costs and benefits of resuming the conflict versus sustaining the peace (Quinn et al. 2007).

Building on the peace agreement literature, the elements of durable peace include indicators of conflict management as well as positive (improving quality of life) and negative (improved security) peace: extent of reconciliation, improving governing institutions, improving security institutions, and economic development. (For more on these particular variables, see Diehl and Druckman 2010, 2013). We elaborate on each of the four components of durable peace below.

In many ways, efforts to promote reconciliation seek to redress past offenses, such as through the creation of a formal truth and reconciliation process, payment of reparations, efforts to rebuild community relationships, and provisions to assist refugees (e.g., Hayner 2011). The growing field of transitional justice focuses on these and related strategies to address the legacy of human rights abuses, with the objective of contributing to the foundation of societal peace. The reconciliation component overlaps with indicators used to assess transitional justice in the post-conflict period, such as the post-conflict justice variables identified by Binningsb $\emptyset$ et al. (2012): trials, truth commissions, reparations, amnesties, purges and exiles. As the Thoms et al. (2010) review of the transitional justice literature reveals, however, there is insufficient empirical evidence that trials and truth commissions have state-level effects, leading us to incorporate a wider span of elements into our durable peace (DP) index, including reception and reintegration (whether initiatives have sought to reintegrate former combatants, refugees or the general population, or to provide reparations to victims), community reconciliation, provisions for refugees, and a variety of institutional components.

Forward looking elements of DP include efforts to construct governance, security and economic institutions. As Paris notes, democratic politics and capitalist economics "depend on public institutions to uphold rules, to maintain order, to resolve disputes 
Table 1 Components of durable peace

\begin{tabular}{|c|c|c|c|}
\hline Reconciliation & Security institutions & Governance institutions & Economic stability \\
\hline $\begin{array}{l}\text { Truth and reconciliation } \\
\text { process created and } \\
\text { redressing of past } \\
\text { crimes } \\
\text { Reparations, reception } \\
\text { and reintegration } \\
\text { Community reconcilia- } \\
\text { tion/relationships } \\
\text { Provisions for refugees }\end{array}$ & $\begin{array}{l}\text { Military reform } \\
\text { Police reform and } \\
\text { local protection } \\
\text { Demobilization, } \\
\text { disarmament } \\
\text { Violent crime }\end{array}$ & $\begin{array}{l}\text { Power } \\
\text { sharing/transitional } \\
\text { government } \\
\text { Rule of law, legal } \\
\text { reform, constitutional } \\
\text { changes } \\
\text { Electoral reform, free } \\
\text { and fair elections, } \\
\text { voter turn-out } \\
\text { Human rights } \\
\text { protection }\end{array}$ & $\begin{array}{l}\text { Increasing income equality } \\
\text { (or decreased concentration } \\
\text { of wealth), improved living } \\
\text { standards } \\
\text { Increased support programs } \\
\text { from lending institutions } \\
\text { (IMF, world bank) } \\
\text { Conditions/policies for } \\
\text { sustainable economic } \\
\text { growth }\end{array}$ \\
\hline
\end{tabular}

impartially, and to regulate behavior incompatible with the preservation of market democracy itself" (2004: 205). Likewise, Doyle and Sambanis' evaluation of United Nations peacekeeping missions argues that peacebuilding requires not only the provision of temporary security, but also building new institutions that can help resolve future conflicts peaceably and building an economy that offers "civilian employment to former soldiers and material progress to future citizens" (2006: 5). Acknowledging challenges to peacebuilding, Doyle and Sambanis also note that participatory, positive peace "is worth striving for (hence measuring)" (2006: 19). Hartzell and Hoddie (2003) suggest that it is not just institution building, but power sharing within these institutions, that contributes to enduring peace.

Security institutions would incorporate military and police reform, demobilization and disarmament of former combatants, and whether the post-conflict society is experiencing low violent crime and the ceasefire still holds (e.g., Diehl and Druckman 2010; United Nations 2000). Governance institution building also offers a measure of the level of stability within a country emerging from civil war (e.g., Cousens et al. 2001). How has a transitional government or power-sharing arrangement held up in practice? Have legal reform, constitutional changes, electoral reform and human rights protection provisions been enacted? Matanock's (2016) work concludes that provisions for elections that result in the participation of both warring sides contribute to lasting peace; free and fair elections matter for achieving durable peace.

Economic stability is, in part, a function of improved living standards and the development of policies and institutions that promote sustained economic growth (e.g., O'Reilly 2014). Quinn et al. (2007: 168) highlight that "the most consistent finding across all studies is that economic underdevelopment... is a significant predictor of civil war onset." It may also be a predictor of civil war duration. Support from outside actors, including the World Bank and the International Monetary Fund, seeks to jump start a country's economy (e.g., Ball and Halevy 1996). In addition, such assistance is usually tied to the condition that a government will pursue certain economic policies, further embedding the changes into the economic framework. These changes may prevent, dampen, or help to terminate a civil war. Table 1 identifies the components of durable peace, as discussed in the peace agreements literature. 
The identification of the components for durable peace is only half the battle: research with this variable requires a carefully constructed index. The variable will be most useful for research on peace agreements if it is not assessed in conjunction with the provisions of the peace agreements themselves. Therefore, DP, and the data sources used to identify it, must focus on the existence of the components several years after a peace agreement has been struck, rather than the implementation of provisions in a peace agreement.

To construct an index for the DP variable, a trained coder reviewed the qualitative news clippings related to each of the four DP components in the peace accords matrix (Kroc Institute for International Peace Studies 2013) as well as data in the Uppsala Conflict Data Program (UCDP 2013) and other sources. ${ }^{1}$ For each case, this coder used a four-step scale for each element of the DP components, as summarized in Table 1. The scores were averaged to create a single code for each DP component, and those codes were assessed for the replicability of the scores, with a second coder making blind coding assessments based on the case material. This was followed by a discussion between the first and second coders aimed at resolving any differences, with each code reconciled by discussion. As shown in the online Appendix ${ }^{2}$, the first and second coder's assessments matched on $86 \%$ of the DP components.

This research approach distinguishes between DP and stable agreements (SA). Stable agreements, as measured by Downs and Stedman, involve cases in which "largescale violence is brought to an end while the [peacekeeping] implementers are present" and "the war is terminated on a self-enforcing basis so that the implementers can go home without fear of the war rekindling" in a 2-year period (2002: 50). This variable tells us whether the peace agreement still exists on paper, and thus offers a proxy for whether there has been some level of management of the conflict. But real, lasting peace involves more than an assessment of breaches and violations of an agreement. Durable peace is a complex, multidimensional concept that includes both conflict resolving (reconciliation) and institutional (security, governance and economic) building during the post-agreement period (Diehl and Druckman 2010; Paris 2004). To evaluate whether the proposed DP index can bring new insights to our understanding of peace agreement negotiations and the management and resolution of the conflict, we include both DP and SA measures in our analyses, relying on an existing data set for the SA measure.

\section{Stable Agreements and Durable Peace}

We would expect civil war conflicts that have been resolved through peace agreements to illustrate a connection between the traditional measure of the stability of the agreement and the newly constructed durable peace index. Indeed, examples can be placed in the cells of a matrix representing each combination of SA and DP. The 1992 peace accord between Renamo and Frelimo in Mozambique ended the war and led to societal changes that paved the way to democratic institutions (high SA and high DP).

\footnotetext{
1 A full list of sources for each of the components of the DP index is available from the authors.

2 The online version of this article (doi:10.1007/s10726-016-9511-9) contains supplementary material.
} 
Table 2 Stable agreements and durable peace

Stable Agreements (SA)

\begin{tabular}{|l|l|l|l|}
\cline { 2 - 4 } $\begin{array}{l}\text { Durable } \\
\text { Peace (DP) }\end{array}$ & High & $\begin{array}{l}\text { Migh } \\
\text { Sozambique (1992) } \\
\text { South Africa (1993) }\end{array}$ & \\
\cline { 2 - 4 } & Low & $\begin{array}{l}\text { Nagorno-Karabakh } \\
(1994)\end{array}$ & Angola (2002) \\
Senegal (2004) & Somalia (1997) \\
\hline
\end{tabular}

Another example of SA and DP success is the 1993 National Peace Accord signed in South Africa. The 1994 cease-fire agreement between Armenia and Azerbaijan over Nagorno-Karabakh effectively ended the war without significant incidents of violence between these countries. However, DP remains a goal still being sought by the international community (Mooradian and Druckman 1999) (high SA but low DP). The 2004 Zinguinchor Peace Agreement between the Government of Senegal and the MFDC is an example of a civil war that ended with a stable agreement but not lasting peace. (See also Paris 2004, for other examples of cases where durability of a peace agreement does not lead to durable peace). But there are many examples of agreements that neither held nor led to peace. A case in point is the 2002 Luanda agreement in Angola (low SA and low DP) and the 1997 peace accord was one of many failed settlements of the civil war in Somalia. Only rare examples exist of DP that emerged despite the breakdown of an agreement. These examples are shown in Table 2.

These cases illustrate variability in the relationship between SA and DP. The variability turns on a connection between conflict management and resolution. SA sets the stage for DP when parties address the sources of conflict. Progress toward reconciliation and institution-building is made when parties adhere to the agreement's provisions and peacekeepers depart. Trust accumulates with experience and facilitates the challenging tasks of peace-building. Progress toward DP may not occur when the agreement serves only to manage the conflict or end the war without addressing its sources. The relationship between SA and DP, as well as other relationships, are explored with a larger data set.

\section{Justice and Peace}

In their search for peace, parties strive to obtain fair and mutually-acceptable agreements. This includes "... redress for the injustices of the past and the establishment of equality and dignity for the future" (Zartman and Kremenyuk 2005: 5). The nexus between the goals of justice and peace is highlighted in the context of civil wars where justice issues are the source of conflict. Wars are prolonged and peace agreements are more difficult to attain when these issues are not resolved. The agreements are also less likely to endure when justice claims are left on the table. The justice-peace relationship was explored in earlier research. (For a more general discussion of the role played by justice in negotiation, see Druckman and Wagner 2016.) 
In their examination of peace agreements reached during the 1990s, Druckman and Albin (2011) find that distributive justice (DJ) principles in the peace agreement outcome provisions (including equality, proportionality, need and compensation) enhance SA during the first few years after the agreement was reached. Taking the examination further, they incorporate Downs and Stedman's (2002) measure of the difficulty of the conflict environment, and find that agreements based on one or more of the four DJ principles reduce the negative impact of a difficult conflict environment on SA. Furthermore, the DJ principle of equality is found to account for this relationship through its mediating role between difficult conflict environments and SA.

When procedural justice $(\mathrm{PJ})$ principles (including transparency, fair representation, fair play and voluntary agreement) are manifest in the negotiation process (HollanderBlumoff and Tyler 2008; Kass 2008; Wagner and Druckman 2012) and manifest are added to the analysis (Albin and Druckman 2012), the relationship between PJ and SA is also found to be mediated by equality. This relationship holds especially for cases where equality entailed provisions for equal treatment (non-discriminatory treatment and equal opportunities) and equal shares (sharing of political authority). However, when equality entailed provisions for equal measures (disarmament and demilitarization), the agreements were less stable or no more stable than "agreements based on other (or no) justice principles" (Albin and Druckman 2012: 177).

We assess DP for each of the 16 cases that both Albin and Druckman (2012) and Downs and Stedman (2002) examined. The assessment is organized in terms of hypotheses that relate DP to SA and to the procedural and outcome justice variables.

\section{Hypotheses}

A set of hypotheses serves to organize our analyses of DP with the existing data set. Stated as alternatives to the Null hypothesis, this set extends the previous analyses from a focus on SA to DP. Although the hypotheses are based on previous research, we regard the evaluations of them as exploratory, as a trial run. Extending the earlier research to DP, we are particularly interested in learning about how the index adds value to our understanding of peace. First, we hypothesize that the durability of agreements is correlated with durable peace. A high correlation would suggest that the former can serve as a proxy for the latter and may be influenced by justice variables in similar ways. A low to moderate correlation would suggest that these variables are relatively independent.

H1 Stable agreements correlate with durable peace: If a peace agreement has high (low) durability, then it will also have high (low) durable peace.

The stronger the relationship between SA and DP, the more likely it is that the justice variables will produce similar impacts. However, if the correlation is moderate or low, then we would expect to obtain different relationships between DP and the justice variables. As noted above, earlier results showed that equality mediated the relationship between PJ and SA (Albin and Druckman 2012). As well as between the difficulty of the conflict and SA (Druckman and Albin 2011). A strong relationship between SA and DP, as assessed by H1, would suggest that the empirically-derived 
path from PJ to DJ equality to SA can be extended to DP. These relationships are captured in three hypotheses. The second hypothesis posits that equality mediates the relationship between PJ and DP. A third hypothesis describes the mediating effects of equality on the relationship between conflict intensity and DP. A fourth hypothesis suggests that SA mediates the relationship between equality and DP.

H2 Equality mediates the relationship between PJ and DP.

H3 Equality mediates the relationship between conflict intensity and DP.

H4 SA mediates the relationship between equality and DP.

We also explore whether there are relationships among particular DP components and justice principles. For example, the DJ principles, especially that of equality, would be expected to facilitate efforts at reconciliation. Kabanoff shows that "equity was the preferred principle when productivity was emphasized, and equality was chosen when solidarity was the goal" (1991: 420). This finding suggests that equality and reconciliation will be correlated; it also suggests a relationship between equity (proportionality in our DJ coding scheme) and economic stability.

These relationships suggest the following hypotheses:

H5 The more significant the DJ principle of equality is in the articles of the peace agreement, the more likely parties will reconcile their differences in the post-conflict period.

H6 The more significant the DJ principle of proportionality is in the articles of the peace agreement, the stronger the economic stability of the country.

The relationship between proportionality principles and economic growth or stability $^{3}$ also has implications for a more general debate about economic growth following civil wars. Is there a relationship akin to the peace dividend, where the end of warfare (and spending on warfare) leads to greater, general economic growth (see Markusen et al. 2003; Collier 1999 for example)? Or is post-agreement economic stability skewed in the direction of the more powerful party (see Coleman and Mazzaro 2013; Wennmann 2009, for example), meaning that any economic benefits accrue, usually, to the government in civil war termination and may not lead to general economic stability? Indeed. this is implied as well by $\mathrm{H} 6$ above.

Focusing directly on civil wars, O'Reilly's (2014) study on the economics of civil war recovery provides clarification for the peace dividend hypothesis. He analyzed investment as a percentage of GDP and the presence of investment-protecting institutions in civil wars occurring from 1965 to 2000. His regression-based results showed conditional support for the peace dividend hypothesis formulated by Collier (1999). Private investment can lead to post-conflict economic recovery when institutional structures have been established. Weak or uncertain institutions prevent investment

\footnotetext{
3 When referring to post-war economic development, we consider both growth and stability. Throughout the article we use the word "stability." This is done in the interest of economy of expression. The word is meant to include both growth and stability.
} 
from contributing to economic recovery. Since institutions take time to develop, economic recovery is likely to be stalled. O'Reilly (2014) suggests that institutional development takes at least 6 years following the dislocations caused by civil wars. The 8 year period examined in this study may be insufficient to allow for positive economic effects from post-war investment to accrue. Thus, economic stability is unlikely to be a benefit of the first 8 years of post-war recovery.

These arguments suggest competing hypotheses about the peace dividend. Following Markusen et al. (2003) and Collier (1999), we suggest that:

H7 Economic stability occurs during the post-civil-war recovery. It correlates with other aspects of durable peace, specifically reconciliation, security institutions and governance institutions.

Following Coleman and Mazzaro (2013) and O'Reilly (2014), we suggest that:

H7a Economic stability does not occur during the post-civil-war recovery period. It is uncorrelated with other aspects of durable peace, specifically reconciliation, security institutions, and governance institutions.

Turning to the negotiation process, the way that PJ principles are incorporated into the negotiation of a peace agreement may have relevance for DP. The inclusion of all relevant parties in the negotiation and the transparency of the process could influence whether several DP elements occur during the post-conflict period, including reconciliation, power sharing, electoral reform, voter turnout and military and police reform. Tyler and Blader (2003), for example, highlight the role of procedures in shaping peoples' social identity within groups, which in turn shape values, attitudes and behavior. Further, fair treatment during the negotiation process, particularly the ability to express one's positions, has been shown to lead to more positive evaluations of the negotiation itself as well as the fairness of the outcome (Tyler 1987; Lind et al. 1990).

Following this reasoning, we expect to find that:

H8 The more significant PJ principles are during the negotiation process, the more durable the peace.

The earlier research showed a strong correlation between SA and conflict intensity with less stable agreements occurring in more intense conflict environments (Druckman and Albin 2011). The hypothesized correlation between SA and DP (see H1) suggests that the intensity of conflict will have similar effects on both variables, leading to the following hypothesis.

H9 Conflict intensity correlates negatively with durable peace: Less durable peace occurs in more conflictual environments.

Considering the time-lagged sequence of these variables suggests that conflict intensity ("difficulty") influences DP through SA. Thus, the following hypothesis is suggested. 
H9a Stable agreements mediate the relationship between conflict intensity and durable peace: Less conflict intensity leads to more stable agreements which, in turn, enhance the durability of peace.

The earlier research on SA also showed that the distributive principle of equality mediated the relationship between conflict intensity and SA: Equality reduced the impact of intense conflict environments on an agreement's durability. Since SA is hypothesized to correlate with DP (see H1) and mediate the relationship between conflict intensity and DP (see H9a), we suggest similar mediating effects for equality, expressed as follows in a final hypothesis:

H9b The principle of equality mediates the relationship between conflict intensity and durable peace: The negative correlation between conflict intensity and durable peace is reduced when equality is central in the peace agreement.

The 9 hypotheses presented in this section focus primarily on DP and its components. Of particular interest are direct and indirect relationships among aspects of justice (DJ, equality, proportionality, and PJ) and DP (reconciliation, security institutions, governance institutions, and economic stability), in comparison with previously identified relationships with the former variables and SA. These hypotheses also address relationships among the components of DP as well as the conflict environment, to further examine the newly constructed DP index. The data set described in the next section was compiled to evaluate these hypotheses.

\section{Data Set and Variables}

To explore the DP index through this set of hypotheses, we examine sixteen civil war cases: Angola I (Bicesse Accords; 1991), Angola II (Lusaka Protocol; 1994), Bosnia (Dayton Agreement; 1995), Cambodia (Paris Agreement; 1991), El Salvador (Chapultepec Agreement; 1992), Guatemala (Guatemala City Agreement; 1996), Lebanon (Ta'if Accords; 1989), Liberia (Abuja Accord; 1995), Mozambique (Rome General Peace Agreement; 1992), Namibia (Protocol of Geneva; 1989), Nicaragua (Esquipulas II/Arias Peace Plan; 1987), Rwanda (Arusha Accord; 1993), Sierra Leone (Abidjan Peace Agreement; 1996), Somalia (Addis Ababa Agreement; 1993), Sri Lanka (IndoLanka Accord; 1987), and Zimbabwe (Lancaster House Agreement; 1979).

These cases were used in analyses conducted by Druckman and Albin (2011), Albin and Druckman (2012), and Downs and Stedman (2002). The cases were originally selected by Downs and Stedman to include instances between 1979 and 1997 where warring parties in a civil war reached a peace agreement and international actors were expected to play a large role in the implementation of the agreement. The cases include a variety of agreement types, from comprehensive to limited or "flimsy," and include a variety of interveners in the first 2 years after the agreement is signed (Stedman 2002).

By adding an important, new variable (DP) to the previous studies, we are able to further explore the relationships identified in the earlier research. The focus of these studies on the relationship between justice during the negotiation stage and peace 
during the post-conflict stage fills a lacuna in the literature: More attention has been paid to the negotiation process and peace agreements themselves. This is due in part to the challenges of accessing data and narrowing down possible post-conflict variables as well as to challenges in developing strategies for comparing cases across contexts and historical periods. The large number of potentially significant variables calls for an iterative research process, with subsequent projects building on previous findings and bringing in additional variables. The justice and conflict environment variables are defined in this section. The DP and SA variables are constructed using the definitions already noted. The coding procedures and reliability evaluations are summarized in a table included as an online Appendix.

\subsection{Distributive and Procedural Justice}

This study explores two types of justice as independent variables. The Druckman and Albin (2011) study focused on DJ in the 16 agreements and explored its impact on the durability of those agreements. They coded the agreement texts according to four principles - equality, proportionality, compensatory justice, and need. Equality refers to elements in the agreement in which there is an equal distribution of resources or burdens among the negotiators (Deutsch 1985). Proportional agreements indicate that negotiators agreed to a distribution relative to negotiators' inputs; it is referred to also as equity (Adams 1965). A compensatory distribution of resources would involve a division that indemnifies one or more parties for undue costs or burdens (Piaget 1948; Solomon and Druckman 1972). The distribution of resources based on parties' needs would signify that negotiators agreed to text that assigns value in proportion to the strength of one or more party's needs (Burton 1986). As indicated in the online Appendix, each portion of the agreement is assessed for whether it reflects one of the DJ principles as well as for its significance, or centrality, to the overall agreement. The inter-coder agreement on assigning codes to the DJ categories is impressive $(r=.87$; $p<.001)$.

The Albin and Druckman study (2012) focused on the PJ variable and explored hypotheses regarding correlations among the PJ principles, the negotiated agreements and their durability as well as the role played by PJ in the relationship between equality and stable agreements. PJ is defined in terms of four principles: transparency, fair representation, fair treatment and fair play, and voluntary agreement. Transparency in a negotiation signifies an openness and accessibility to information related to the decision-making process and its outcomes (Heald 2006). Fair representation indicates that parties, interests and other relevant stakeholders have a voice in the negotiation process (Leventhal et al. 1980; Thibaut and Walker 1975). Fair treatment and fair play refers to whether the participating parties have the opportunity to influence the process, beyond being invited to the table (Lind and Tyler 1988). Voluntary agreement is the extent to which proposals are freely accepted rather than being imposed (Barry 1996; Albin 2001). Data for each part of PJ were found in primary and secondary accounts of the talks. PJ was assessed in terms of the significance of the principles to the negotiation process, and the reliability calibrations were impressive as shown in the online Appendix. 
Transitional justice - another type of justice discussed in the literature-focuses on implementation and includes such elements as truth and reconciliation commissions, trials, and reparations. We incorporate these and other aspects of transitional justice in our durable peace variable, treating them as part of a broader index of long-term peace, and measuring them based on the level of existence during the post-agreement period rather than based on whether the peace agreement included provisions calling for these elements.

\subsection{Conflict Environment}

Downs and Stedman (2002) created a "difficulty" variable for the 16 cases examined. This variable focuses to a large extent on options that are available to those with power. Their index aggregates scores for the following eight categories: number of warring parties; lack of a peace agreement before intervention or a coerced peace agreement; likelihood of spoilers; existence of a collapsed state; number of soldiers; presence of disposable natural resources; presence of hostile neighboring states or networks; and demands for secession. A regression analysis showed that three of the difficulty variables relate significantly to implementation success-existence of a spoiler, presence of disposable resources, presence of a hostile neighboring statealthough they note that the existence of a spoiler and hostile neighbor are closely related variables.

The difficulty variable offers an assessment of the external environment within which leaders operate. This environment shapes the strategic options available to, or motivating, the actors in leadership roles. ${ }^{4}$

The variables, coding procedures, and reliability assessments are summarized in the online Appendix. We turn next to the statistical analyses used to evaluate the DP index, using the set of hypotheses.

\section{Results}

The data are organized by cases and variables in Table 3. The hypotheses serve to organize the sequence of analyses performed to evaluate impacts on DP and its component indices. These analyses consist of a mix of correlational or bi-directional $(\mathrm{H} 1$, H7, H7a, H9) and causal or uni-directional statements (H2, H3, H4, H5, H6, H8, H9a, $\mathrm{H} 9 \mathrm{~b})$. The former hypotheses were evaluated with correlations (bivariate and partial). The latter were evaluated with correlation, regression, and regression-based mediation analyses for indirect effects. The justice and peace variables are sequenced or time lagged in the direction of $\mathrm{P} \longrightarrow \mathrm{D} \leftrightarrow \mathrm{SA} \rightarrow \mathrm{DP}$. Thus, the causation assumption is plausible and provides a basis for the regression analyses.

A correlation matrix is shown in Table 4. Three of the four components of the DP index are strongly correlated with the aggregate index and with each

\footnotetext{
4 We are developing an index on the internal aspects of the conflict environment, including months of violence, average number of deaths, and internally displaced persons. These indicators are an attempt to assess the state of the population and will be interesting to include in future analyses.
} 
Table 3 Cases by variables

\begin{tabular}{llllllll}
\hline Country & SA & DP & DJ & Equality & Proportionality & PJ & Difficulty \\
\hline Zimbabwe & 3 & 1.83 & 3.75 & 2 & .67 & .8 & 4 \\
Sri Lanka & 1 & 1.17 & 3 & 1 & 0 & .5 & 6 \\
Namibia & 3 & 2.58 & 4.25 & 2 & 0 & .81 & 0 \\
Nicaragua & 3 & 2.55 & 3.5 & 1.33 & 0 & .83 & 1 \\
Lebanon & 2 & 1.86 & 3 & 1.67 & 1.33 & .63 & 5 \\
Liberia & 2 & 1.23 & 1.25 & .67 & 0 & .8 & 6 \\
Angola I & 1 & 1.25 & 2.75 & 1.33 & 0 & .83 & 4 \\
Cambodia & 2 & 1.57 & 1.5 & 1.33 & 0 & 1.06 & 5 \\
Mozambique & 3 & 2.52 & 4.5 & 2 & .67 & 1.1 & 3 \\
El Salvador & 3 & 2.63 & 2.5 & 1.33 & 0 & 1.08 & 1 \\
Somalia & 1 & 1.44 & 3.5 & 1 & 0 & .75 & 5 \\
Rwanda & 1 & 1.25 & 4 & 1 & .67 & .79 & 3 \\
Angola II & 1 & 1.81 & 0 & 0 & 0 & .5 & 4 \\
Bosnia & 2 & 1.97 & 3.5 & 1.67 & 1.33 & .75 & 6 \\
Guatemala & 3 & 2.23 & 3.25 & 2 & 0 & .9 & 0 \\
Sierra Leone & 1 & 1.83 & 2 & 0 & 0 & .5 & 6 \\
\hline
\end{tabular}

${ }^{a}$ Data on each of the DP components are available from the authors

other: Reconciliation-Security (.63); Reconciliation-Governance (.48), and SecurityGovernance (.69). The economic stability component does not correlate with the aggregate index or with any of the other DP components. Thus, the results presented in this section are based on a three-component index and include analyses of the aggregate as well as its parts. They are organized in terms of the hypotheses.

H1 Stable agreements correlate with durable peace: If a peace agreement has high (low) durability, then it will also have high (low) durable peace.

The correlation between SA and DP is very strong at .80, $\mathrm{p}<.0001$. This relationship is robust. The size of the relationship decreases only slightly or not at all when controlling for each of the other variables shown in Table 3: difficulty (.63), PJ (.76), DJ (.77), equality (.78), and proportionality/equity (.80). Table 5 reprises Table 2 for the 16 cases. The cases are sorted by mean values for SA and DP, illustrating the strong relationship between these variables. Thus $\mathrm{H} 1$ is supported.

H2 Equality mediates the relationship between PJ and DP.

H3 Equality mediates the relationship between difficulty and DP.

H4 SA mediates the relationship between equality and DP.

Regression-based mediation analyses showed that equality did not mediate the relationship between $\mathrm{PJ}$ and $\mathrm{DP}(\mathrm{H} 2)$ or between difficulty and $\mathrm{DP}(\mathrm{H} 3)$. Only difficulty produced a significant regression coefficient with DP $(p<.01)$. PJ and equality 


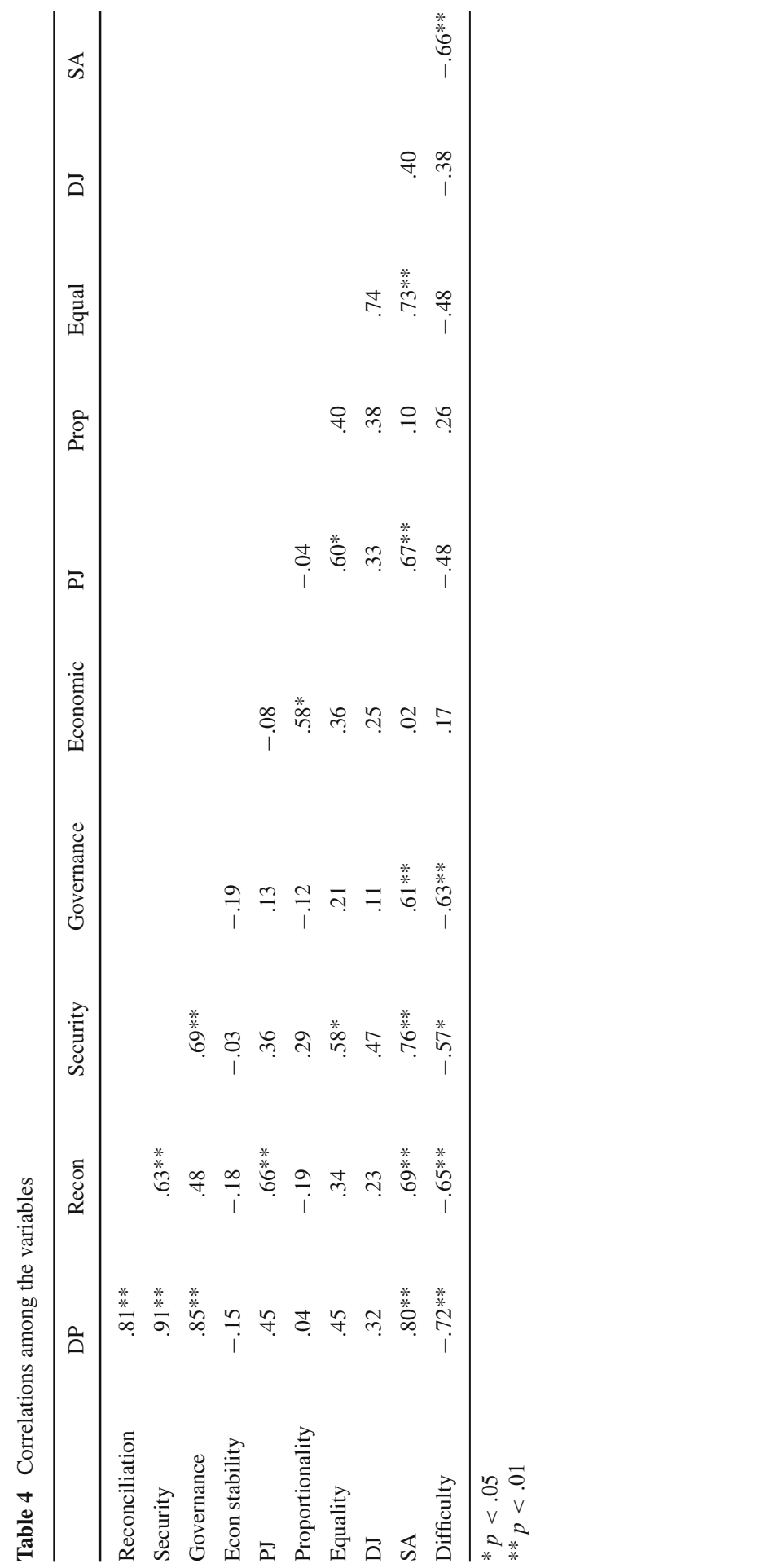


Table 5 Cases organized by stable agreements and durable peace

Stable Agreements (SA)

\begin{tabular}{|l|l|l|l|}
\hline & & High [above mean] & Low [below mean] \\
\cline { 2 - 4 } $\begin{array}{l}\text { Durable } \\
\text { Peace (DP) }\end{array}$ & High & Mozambique & Lebanon \\
[above & Zimbabwe & Bosnia \\
mean] & $\begin{array}{l}\text { Namibia } \\
\text { Nicaragua } \\
\end{array}$ & $\begin{array}{l}\text { El Salvador } \\
\text { Guatemala }\end{array}$ & \\
& & & Sri Lanka \\
& Low & & Liberia \\
& [below & & Angola I \\
mean] & & Cambodia \\
& & Somalia \\
& & Rwanda \\
& & Angola II \\
& & Sierra Leone \\
& &
\end{tabular}

Cases sorted by mean values (High SA $>1$; High DP $>1.8$ )

produced borderline regression coefficients with DP at $p<.09$ and .08 respectively. PJ did, however, regress significantly on equality at $p<.01$.

Equality correlates strongly with SA at .73, but not with DP at .45. The strong correlation between equality and SA (.73) reduces only slightly (to .69) when controlling for DP. However, equality relates to DP indirectly through SA. Results from a mediation analysis using Sobel's z statistic (Sobel 1982) shows that SA is a significant mediating variable ( $p<.02$, two-tailed) between equality and DP as follows:

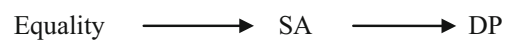

This path supports H4. Even stronger mediation effects for SA occur with each of the components of the DP index: reconciliation at $p<.001$; security institutions at $p<.008$, and governing institutions at $p<.001$. SA does not mediate the relationship between equality and economic stability $(p>.15)$.

H5 The more significant the DJ principle of equality is in the articles of the peace agreement, the more likely parties will reconcile their differences in the post-conflict period.

H6 The more significant the DJ principle of proportionality is in the articles of the peace agreement, the stronger the economic stability of the country.

We do not find a significant correlation between equality and reconciliation (.34). Thus, hypothesis 5 is not supported. This result also suggests that solidarity may not be a primary objective of these negotiations. Economic stability correlates significantly with the DJ principle of proportionality (.58). This relationship is robust. Neither economic stability nor proportionality correlate with any of the other variables (see Table 4); the correlation remains the same when each of the other variables is controlled (equality, PJ, SA, DP). This relationship is reflected as well in the results of an 
exploratory factor analysis. The economic stability element of DP and the proportionality principle of DJ are isolated, and loaded on a second factor by themselves. Thus, hypothesis 6 is supported.

H7 Economic stability occurs during the post-civil-war recovery. It correlates with other aspects of durable peace, specifically reconciliation, security institutions and governance institutions.

H7a Economic stability does not occur during the post-civil-war recovery period. It is independent of other aspects of durable peace, specifically reconciliation, security institutions, and governance institutions.

As noted at the beginning of this section, economic stability is not correlated with any of the other components of the DP index or with the aggregated index. As shown just above, it correlates only with the DJ principle of proportionality and loads on a factor separate from the other DP components and types of justice. These results support H7a but not H7. This component of the DP index is independent of other aspects of durable peace.

H8 The more significant PJ principles are during the negotiation process, the more durable the peace.

PJ correlates significantly with reconciliation (.66) but not with the security or governance components of DP. This finding provides partial support for H8. PJ also correlates strongly with SA (.67). A regression-based mediation analysis, based on Sobel's z statistic (1982), shows that the variables take the form of a path with SA mediating the relationship between $\mathrm{PJ}$ and reconciliation at $\mathrm{p}<.06$ (one-tailed):

$$
\mathrm{PJ} \rightarrow \mathrm{SA} \rightarrow \text { Reconciliation }
$$

H9 Conflict intensity correlates negatively with durable peace: Less durable peace occurs in more conflictual environments.

Conflict intensity ("difficulty") correlates strongly with DP (-.72) and its components at -.65 (reconciliation), -.57 (security), and -.63 (governance). It does not, however, correlate with the economic component (.17) (see Table 4). Thus, hypothesis 9 is supported.

H9a Stable agreements mediate the relationship between conflict intensity and durable peace: Less conflict intensity leads to more stable agreements which, in turn, enhance the durability of peace.

A regression-based mediation analysis shows that durability of the agreement mediates the relationship between conflict intensity and DP. A significant Sobel's z (1.84, $p<.035$, one tailed) indicates the following path, which supports H9a:

$$
\text { Conflict intensity } \rightarrow \mathrm{SA} \rightarrow \mathrm{DP}
$$


Further, the correlation between the measure of conflict intensity and DP reduces from -.72 to -.42 when SA is controlled.

H9b The principle of equality mediates the relationship between conflict intensity and durable peace: The negative correlation between conflict intensity and durable peace is reduced when equality is central in the peace agreement.

Regression-based mediation analyses show that the relationship between conflict intensity and DP is not mediated by the principle of equality. The path from conflict intensity to DP does not go through the principle of equality in the agreements. Thus, $\mathrm{H} 9 \mathrm{~b}$ is not supported.

The correlation between conflict intensity and DP reduces somewhat, from -.72 to -.64 , when equality is controlled. It reduces to -.44 when both SA and equality are controlled. The equality principle is a stronger mediator of the relationship between conflict intensity and SA (Sobel'z $=1.66 ; p<.05$, one-tailed). The correlation between conflict intensity and SA reduces from -.66 to -.52 when equality is controlled.

In sum, the results show a strong correlation between SA and DP, which is further qualified when the DJ principle of equality is added to the analysis: SA mediates the relationship between equality (as an independent variable) and DP (as a dependent variable). SA is shown also to mediate the relationship between equality and each of the DP components except economic stability. As well, SA is shown to mediate the relationships between PJ and reconciliation and between the intensity of conflict and DP. Findings obtained with regard to the economic stability variable are also interesting. This variable correlates only with the DJ principle of proportionality or equity. It does not correlate with any of the other components of the DP index. We turn now to a discussion of these findings.

\section{Discussion}

The results provide a number of insights about the durability of peace and the role of justice in sustaining peace following negotiation. First, we learn about the relationship between the SA and DP concepts. Second, we find that procedural and distributive justice play an important role in this relationship. Third, the link found between PJ during the process and equality provisions in the agreements calls attention to the importance of trust in negotiation. Fourth, the analyses of the DP components reveal differences among them in the way that justice operates. Fifth, the peace dividend hypothesis with regard to economic development and growth is called into question. And, sixth, we learn about the impact of the external conflict environment on durable peace. These findings corroborate earlier results on the relationship between justice and SA. They also reveal new findings about the justice-peace nexus. Thus, we conclude that the approach adds value to the study of peace agreements and their implementation. Each of the findings is discussed in turn followed by suggestions for next steps in the research program.

The distinction between DP and SA is of particular interest for understanding the value of the DP variable for the examination of peace agreements. The substantial 


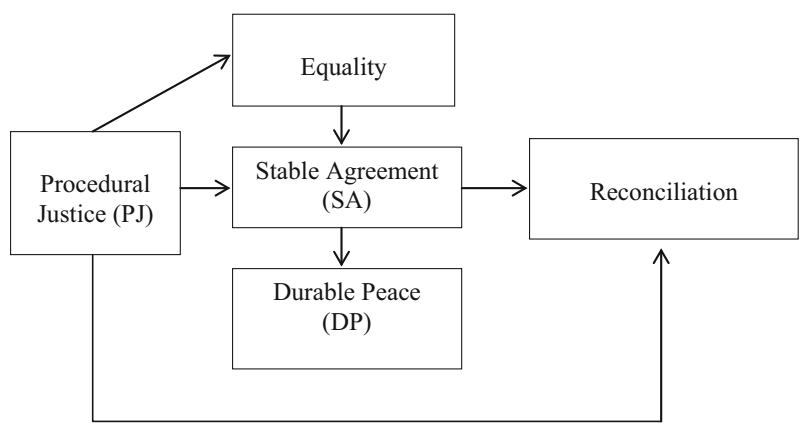

Fig. 1 Relationships among the variables

correlation between SA and DP suggests that these concepts may be interchangeable. The path analyses show that DP eventuates when SA is achieved and justice principles are adhered to. Because they are highly correlated does not mean that they are interchangeable, however. Taking the time lag between these variables into account suggests that the relationship is sequential rather than overlapping: The two-year period of peacekeeping (SA) is followed by six more years of reconciliation and institution building (DP). These cases illuminate a continuity between managing (peacekeeping) and resolving (peacebuilding) the conflict. This finding is similar to results reported by Quinn et al. (2007). Their study of war recurrence indicates that "the longer the peace can be sustained, the less likely it is to break down" (2007: 189).

Further analyses reveal that justice also plays an important role in this relationship. When DJ and PJ are included in the analyses, SA is shown to have a mediating function. It serves as a bridge between the DJ principle of equality (support for H4) and DP as well as between PJ and the DP reconciliation component (partial support for H8). Equality relates to DP through SA: The direct relationship between equality and DP is modest with a correlation of .45 . PJ relates strongly to both SA (at .67) and to reconciliation (at .66), indicating that both direct and indirect relationships occur among the three variables. Equality also plays a role in this path: It mediates the relationship between PJ and SA but does not extend to longer-term reconciliation. Equality is linked more strongly to SA than to DP or its components whereas PJ is linked strongly to both SA and the DP reconciliation component. This system of relationships is summarized in the form of paths shown in Fig. 1.

Of interest are questions about why these sequences occur. Equality in peace agreements appears to set the stage for lasting peace through its impact on short-term implementation. Equality also reduces the negative impact of intense conflict environments on durability (SA). By managing the conflict, equality gives peacekeepers an opportunity to transition to a stage where the agreements are self-enforcing and peace-building activities take over (see also Binningsbø et al. 2012). Hartzell and Hoddie (2003) suggest that it is not just institution building (DP components in the current study), but power sharing (the DJ principle of equality) within these institutions that contributes to peace; the agreement provisions for equal sharing of power, when implemented as institution building, lead to DP. Similarly, Call (2012) finds that including former combatants in postwar governance contributes to sustained peace. 
Badran's (2014) identification of a relationship between the substantive complexity of the agreements themselves and the duration of peace is relevant in this respect, reinforcing the linkages between the qualities of the agreement text, stable agreements and, ultimately, durable peace.

As noted in earlier research (Albin and Druckman 2012), the salience of the DJ equality principle renders it a focal point for coordinating grievances from rebel parties with demands made by the incumbent government. This finding is reflected in Park's study, which suggests that some predictions by traditional bargaining theories do not apply for civil war negotiations: "warring groups do not seem to make bargaining demands that closely follow their share of relative power" (2015: 181). The stronger party(ies) may be willing to incorporate the security concerns of the weaker party(ies) into the agreement to ensure that a peace agreement is signed. But, our findings also suggest the possibility that a more fundamental psychological process may be at work, trust building.

The PJ-equality link calls attention to the relevance of developing trust in peace negotiations. Rules involving fair procedures help generate trust even when parties are unequal in power. This trust in turn promotes a willingness to enter into and implement agreements (Oskarsson et al. 2009). A challenge, however, is to sustain the trust needed to move forward with the more ambitious provisions of the agreement. Our results suggest caution with regard to longer-term developments. Although PJ, and the trust it engenders, facilitates peaceful relationships, its primary impact is on the DP component of reconciliation rather than institution building. Reconciliation may well be the area where trust has the strongest impact. Maintaining the trust developed through the process and its outcome is one challenge. Another is how to set in motion a process that allows this good will to reverberate in the direction of sustained efforts toward rebuilding the country's security and governing institutions. A careful tracing of this process may reveal critical moments where transitions occur from one to another stage in the development of lasting peace.

The analysis of the DP components contributes to our understanding of their role in achieving positive peace. The findings in this study include the identification of a sensitivity of reconciliation (a transitional justice variable) to PJ and the estrangement of economic development and investment as discussed also by O'Reilly (2014). These findings have implications for the idea of a peace dividend following civil wars. The lack of correlation between the economic stability component and other aspects of the DP index calls attention to the lack of a dividend. This may be due, at least in part, to the time needed for the development of institutions that would facilitate the investments needed for economic recovery as suggested by O'Reilly (2014). Eight years may be insufficient. If so, then a longer time period for observing economic development is warranted.

It may also be the case that economic issues are not given sufficient attention in the agreements. This is indicated by the results of an analysis of agreement provisions. Each agreement was content analyzed in terms of the four categories of DP: provisions addressing reconciliation, security institutions, governance institutions, and economic stability. All provisions were placed in one of these four categories, resulting in percentages as follows: reconciliation (18\%), security institutions (38\%), governance institutions (37\%), and economic stability (7\%). Thus, the peace agreements in 
this sample emphasized security and governance institutions more than reconciliation or economics. Economic stability was relatively de-emphasized. Conceivably, more attention to economic institutions may have led to growth and stability during the eight years following the agreement. However, this is unlikely. Our further analyses show that the distribution of agreement provisions do not correlate with DP or with any of its components. Nor do the provision percentages correlate with any of the justice variables or with SA. DP (and SA) are driven more by the process and outcome justice variables than the types of provisions in the agreements.

The relationship between difficulty and DP might help explain why economic stability is an outlier in the DP index, and suggests additional issues to consider in light of this relationship. Difficulty correlates significantly and negatively with overall DP $(-.72)$ as well as with three of the components of DP: reconciliation $(-.65)$, security (-.57) and governance (-.63). It does not correlate significantly (or negatively) with economic stability (.17), however. This suggests that more external conflictual environments, as indicated by the difficulty score, would hamper the achievement of reconciliation and the building of security and governance institutions. The implementation of the economic stability variable, on the other hand, depends to some extent on outside actors, such as international financial institutions. It is possible that these institutions, recognizing the difficult situation, redouble their efforts to assist a war-torn country after a peace agreement has been signed. However, as suggested by O'Reilly's (2014) analyses, efforts made by international institutions are likely to be insufficient for developing the internal institutions needed for private investment.

In addition to developing a DP index, this research offers preliminary findings on DP as a positive peace concept. Durable peace, in this study, is achieved through managing conflict (reconciliation) as well as positive peace (building governing institutions) and negative peace (security institutions). Thus, as we note earlier, this is a multidimensional concept with multiple measures. And just as the previous analyses of the 16 cases showed that justice, particularly equality, was important for SA, we show here that these variables are also important for DP. Thus we extend the earlier analyses to long term peace.

These results suggest the viability of using this index in further research, particularly for evaluating hypotheses with a larger, more representative data set. The correlations between the aggregate DP index and three of its components, reconciliation (.82), security (.91) and governance (.85), are all very strong. Correlations between security and reconciliation (.63) and between security and governance (.69) are also strong. These findings suggest an important area for research, namely, to evaluate how these variables interact with each other. Does success with one beget success with the other? Why does the fourth variable in the DP index-economic stability-not correlate significantly with the overall DP variable or with each of the other DP components?

The significant relationship between DJ's equality principle and SA (.73) suggests another area for further research. What is it about equality provisions that drive SA, as measured in the first two years post-conflict, but not DP eight years after the agreement is struck? And how does this finding reconcile with Badran's (2014) identification of a relationship between the substantive complexity of the agreements themselves and the duration of peace? 
The Albin and Druckman (2012) study found a mediating role for the forwardlooking DJ equality principles (equal treatment, equal shares) between PJ and SA, but did not find the same mediating role between the backward-looking equality principle (equal measures), PJ and SA. We do not find a significant correlation between PJ and the more forward-looking DP components of governance and security institutions. But PJ does correlate significantly with reconciliation (.66), raising the possibility that the more backward-looking reconciliation variable is a dividend of the negotiation process rather than of its outcome.

Another research issue is suggested by the findings on conflict intensity, stable agreement, and durable peace. Both stable agreements and durable peace are more likely to occur in less conflictual environments as measured by the existence of spoilers, presence of natural resources, and neighbors that fuel the conflict. The mediation and partial correlation analyses highlight the importance of durable implementation. While being influenced by the intensity of the conflict, a stable agreement is also instrumental in reducing the negative effects of that environment on lasting peace. A next step is to explore how effective implementation occurs in difficult environments and to develop guidelines for peacekeepers on managing the environment in the postagreement phase. Another step entails developing indicators for the intensity of the internal conflict environment, which are in progress (see footnote 5). It would be interesting to learn whether the effects are similar to or different from those found for the external conflict indicators used in this study.

The extent to which these findings capture peace agreements more generally awaits analyses of a broader sampling of cases. The key relationships found in this study between justice, the durability of peace agreements and the durability of peace itself remain to be corroborated with civil-war termination cases that occurred in other time periods between parties contesting a larger variety of issues. ${ }^{5}$ The paths shown in Fig. 1 provide a framework for studies that probe an extended set of cases.

\section{Conclusion}

In this study we evaluated a new index of durable peace referred to as DP. We showed that many of the earlier findings obtained with a measure of stable agreements, referred to as SA, hold as well for DP. But, we also learned that SA mediates the relationship between the DJ principle of equality and DP. Going further, we discovered relationships among the set of variables explored. Elements in the peace agreements that treat the negotiating parties equally, such as equal options for repatriation and for troop demilitarization, correlate positively with the SA feature of a successful reduction of large-scale violence, which then positively influences the durable peace components of governance, security and reconciliation. These findings are summarized in the form

\footnotetext{
5 We are currently analyzing data collected from a large representative sampling of civil-war termination cases from most of the world's continents extending from the 1940s (post WWII) through 2008. The path model in Fig. 1 will be used as a framework to derive hypotheses to be evaluated by those analyses. Thus, we create a bridge between the inductive approach used in this study and a more deductive approach to be used in the next study.
} 
of a path diagram. The finding that economic stability stands out from the other components of DP and does not correlate with the other variables in the study raises interesting questions. In addition, the relationships found between the difficulty and stable agreement variables suggest that the external conflict context deserves further study to ensure that those citizens who are looking for tranquility for their villages and families will be justified when holding up the names of the peace agreements that their leaders sign.

Open Access This article is distributed under the terms of the Creative Commons Attribution 4.0 International License (http://creativecommons.org/licenses/by/4.0/), which permits unrestricted use, distribution, and reproduction in any medium, provided you give appropriate credit to the original author(s) and the source, provide a link to the Creative Commons license, and indicate if changes were made.

\section{References}

Adams JS (1965) Inequity in social exchange. In: Berkowitz L (ed) Advances in experimental social psychology. Academic Press, New York

Albin C (2001) Justice and fairness in international negotiation. Cambridge University Press, Cambridge

Albin C, Druckman D (2012) Equality matters: negotiating an end to civil wars. J Confl Resolut 56(2): $155-182$

Badran R (2014) Intrastate peace agreements and the durability of peace. Confl Manag Peace Sci 31(2): 193-217

Ball N, Halevy T (1996) Making peace work: the role of the international development community. Overseas Development Council, Distributed by Johns Hopkins University Press, Washington, Baltimore

Barry B (1996) Justice as impartiality. Oxford University Press, Oxford

Binningsbø HM, Loyle CE, Gates S, Elster J (2012) Armed conflict and post-conflict justice, 1946-2006: a dataset. J Peace Res 49(5):731-740

Burton JW (1986) The history of international conflict resolution. In: Azar EE, Burton JW (eds) International conflict resolution: theory and practice. Lynne Rienner Publishers, Boulder

Call CT (2012) Why peace fails: the causes and prevention of civil war recurrence. Georgetown University Press, Washington

Coleman PT, Mazzaro K (2013) The beginning of peace? The world post (November 27). http:// www.huffingtonpost.com/peter-t-coleman-phd/global-peace-index_b_4350532.html. Accessed 16 Feb 2014

Collier P (1999) On the economic consequences of civil war. Oxf Econ Pap 51(1):168-183

Cousens EM, Kumar C, Wermester K (eds) (2001) Peacebuilding as politics: cultivating peace in fragile societies. Lynne Rienner Publishers, Boulder

Deutsch M (1985) Distributive justice: a social psychological perspective. Yale University Press, New Haven

Diehl PF, Druckman D (2013) Peace operation success: the evaluation framework. In: Druckman D, Diehl PF (eds) Peace operation success: a comparative analysis. Martinus Nijhoff Publishers, Leiden

Diehl PF, Druckman D (2010) Evaluating peace operations. Lynne Rienner, Bounder

Downs G, Stedman SJ (2002) Evaluation issues in peace implementation. In: Stedman SJ, Rothchild D, Cousens EM (eds) Ending civil wars: the implementation of peace agreements. Lynne Rienner Publishers, Boulder

Doyle MW, Sambanis N (2006) Making war and building peace: United Nations peace operations. Princeton University Press, Princeton

Druckman D (2002) Settlements and resolutions: consequences of negotiation processes in the laboratory and in the field. Int Negot 7(2):313-338

Druckman D, Albin C (2011) Distributive justice and the durability of peace agreements. Rev Int Stud 37(3):1137-1168

Druckman D, Wagner L (2016) Justice and negotiation. Annu Rev Psychol 67:387-413

Fortuna VP (2004) Peace time: cease-fire agreements and the durability of peace. Princeton University Press, Princeton 
Hayner PB (2011) Unspeakable truths: transitional justice and the challenge of truth commissions, 2nd edn. Routledge, New York

Hartzell C, Hoddie M (2003) Institutionalizing peace: power sharing and post-civil war conflict management. Am J Political Sci 47(2):318-332

Heald D (2006) Varieties of transparency. Proc Br Acad 135:25-43

Hollander-Blumoff R, Tyler TR (2008) Procedural justice in negotiation: procedural fairness, outcome acceptance, and integrative potential. Law Soc Inq 33(2):473-500

Kabanoff B (1991) Equity, equality, power, and conflict. Acad Manag Rev 16(2):416-441

Kass E (2008) Interactional justice, negotiator outcome satisfaction, and desire for future negotiations: respect at the negotiating table. Int J Confl Manag 19(4):319-338

Kroc Institute for International Peace Studies, Notre Dame (2013) Peace accords matrix. https:// peaceaccords.nd.edu/matrix/matrix/

Leventhal GS, Karuza J, Fry WR (1980) Beyond fairness: a theory of allocation preferences. In: Mikula G (ed) Justice and social interaction. Springer Verlag, New York

Lind EA, Tyler TR (1988) The social psychology of procedural justice. Plenum, New York

Lind EA, Kanfer R, Earley PC (1990) Voice, control, and procedural justice: instrumental and noninstrumental concerns in fairness judgments. J Personal Soc Psychol 59(5):952-959

Markusen A, DiGiovanna S, Leary MC (eds) (2003) From defense to development? International perspectives on realizing the peace dividend. Routledge, New York

Martin P (2013) Coming together: power-sharing and the durability of negotiated peace settlements. Civil Wars 15(3):332-358

Matanock A (2016) Bullets for Ballots: electoral participation provisions in peace agreements and conflict recurrence. http://matanock.berkeley.edu/wp-content/uploads/Matanock_Bullets-for-Ballots_ June2016.pdf. Accessed 4 Aug 2016

O'Reilly C (2014) Investment and institutions in post-civil war recovery. Comp Econ Stud 56(1):1-24

Oskarsson S, Svensson T, Öberg P (2009) Power, trust, and institutional constraints: individual level evidence. Ration Soc 21(2):171-195

Paris R (2004) At war's end: building peace after civil conflict. Cambridge University Press, New York

Park S (2015) Power and civil war termination bargaining. Int Stud Quart 59(1):172-183

Piaget J (1948) The moral judgment of the child. Free Press, Glencoe

Quinn JM, Mason TD, Gurses M (2007) Sustaining the peace: determinants of civil war recurrence. Int Interact 33(2): 167-193

Salehyan I, Thyne CL (2012) Civil wars. In: Mitchell SM, Diehl PF, Morrow JD (eds) Guide to the scientific study of international processes. Wiley, Hoboken

Sobel ME (1982) Asymptotic intervals for indirect effects in structural equation models. In: Leinhart S (ed) Sociological methodology. Jossey-Bass, San Francisco

Solomon D, Druckman D (1972) Age, representatives' prior performance, and the distribution of winnings with teammates. Hum Dev 15(4):244-252

Stedman SJ (2002) Introduction. In: Stedman SJ, Rothchild D, Cousens EM (eds) Ending civil wars: the implementation of peace agreements. Lynne Rienner Publishers, Boulder

Thibaut JW, Walker L (1975) Procedural justice: a psychological analysis. Wiley, Hoboken

Thoms ONT, Ron J, Paris R (2010) State-level effects of transitional justice: what do we know? Int J Transit Justice 4:329-354

Tyler TR (1987) Conditions leading to value-expressive effects in judgments of procedural justice: a test of four models. J Personal Soc Psychol 52(2):333-344

Tyler TR, Blader SL (2003) The group engagement model: procedural justice, social identity, and cooperative behavior. Personal Soc Psychol Rev 7(4):349-361

United Nations (2000) Report of the panel on United Nations peace operations. United Nations, New York

Uppsala Conflict Data Program. (2013). UCDP conflict encyclopedia. www.ucdp.uu.se/database

Wagner L, Druckman D (2012) The role of justice in historical negotiations. Negot Confl Manag Res 5(1):49-71

Wennmann A (2009) Getting armed groups to the table: peace processes, the political economy of conflict and the mediated state. Third World Quart 30(6):1123-1138

Zartman IW, Kremenyuk V (eds) (2005) Peace versus justice: negotiating forward-and backward-looking outcomes. Rowman \& Littlefield Publishers, Lanham 